\title{
Lingua-Cognitive Structure of Portrait Feature Stories in Media Discourse: A Cross-Cultural View
}

\author{
Tatiana Karpilovitch \\ Minsk State Linguistic University, Minsk, Belarus
}

\begin{abstract}
This paper considers lingua-cognitive characteristics of the genre "a portrait feature story" which functions in American and Belarusian media discourse. We hold the view that the lingua-cognitive parameters for describing discourse genres are their typical semantic structures and conceptual dominants (key concepts) which are regularly represented in the discourse. The cross-cultural analysis of portrait features stories from modern American and Belarusian newspapers has shown the prevalence of common lingua-cognitive properties: They have the same prototypical superstructures "the portrait of the protagonist—background" and similar conceptual dominants of "success" and "work". The main differences lie in the discourse representation of the specific semantic categories and conceptual dominants, which are predetermined by the traditions of choosing by the journalists thematic and semantic structures of portrait feature stories in American and Belarusian media cultures.
\end{abstract}

Keywords: media discourse, portrait feature story, semantic structure, conceptual dominant, cross-cultural analysis

\section{Introduction}

The present stage of society development is characterized by the growth of information created by means of mass media, by the increase of their role in the life of each individual and society on the whole. The increasing importance of mass media has led to the rapid development of media linguistics as an integrated scientific trend which studies structural, semantic, communicative, and pragmatic characteristics of media discourse genres.

This paper presents the results of the cross-cultural analysis of media discourse in one of its genres-portrait feature stories published in American and Belarusian press (in the Belarusian language). The analysis is based on the communicative-cognitive approach to the definition and description of the discourse genre (Karpilovitch, 2010). This approach presupposes the use of communicative parameters realized in the discourse genre (the communicative goal of the author, the addressee and the addresser characteristics, communicative strategies and tactics) and cognitive parameters (semantic structure of the discourse genre and dominant concepts represented in the discourse).

This paper focuses on the cognitive parameters of the discourse genre "a portrait feature story" and means of their language representation in American and Belarusian media discourse. The notion "cognitive parameters" is used in the meaning "lingua-cognitive parameters", since their meaning is inferred mainly from the lexical and

Tatiana Karpilovitch, professor, doctor, Head of the Department of Theory and Practice of the English Language, Minsk State Linguistic University. 
grammatical units of the discourse, not from "external knowledge base" (Sinclair, 1992, p. 82).

\section{Theoretical Frame}

One of the most productive approaches to the study of discourse semantics from the cognitive viewpoint is frame analysis which was first introduced in the sphere of artificial intelligence (Minsky, 1975). According to this method, a frame is a data structure for representing a stereotyped situation (for example, being in the certain kind of living room, going to a birthday party, etc.). This cognitive understanding of the frame has a certain connection with the notion of a schema which, according to the data obtained by cognitive psychology, means an active organization of the previous reactions or past experience. But while the frame was introduced to represent the knowledge about typical situations, the schema was first used in discourse analysis to represent its structure. It should be noted that after Minsky introduced the term frame, linguists and psychologists offered some other terms to denote the same notion, those of script, scenario, and schema. Thus, in the study of narratives (Thorndyke, 1977) discourse is represented as a hierarchical structure in which the upper nodes are occupied by the most important utterances. The main utterance expresses its main idea, while a more detailed structure is represented by such components as circumstances, plot, and denouement, each of which may be represented by a number of subcomponents. Thus, circumstances include the subcomponents of characters, place, and time.

In the theory of Teun van Dijk and Walter Kintsch (1983), the term schema got a new interpretation; they introduced the term superstructure, alongside with the notion of a macrostructure. The superstructure is defined as a conventional global schema of discourse which "may be made explicit in terms of the specific categories defining a discourse type. Macrostructures, then, are the semantic content for the terminal categories of these superstructural schemata" (Dijk \& Kintsch, 1983, p. 189). They can find concrete expression in thematic sentences and in summaries of the discourse.

Though the authors claim that superstructure is the overall form of a discourse (Dijk \& Kintsch, 1983, p. 189) but in the analysis of news stories they consider not only formal categories like headline, lead, summary, and introduction but also the categories which are semantic in nature: "previous information", "actual information", "background", "opinion", "events", "consequences", etc. The authors argue that the sequence of these categories is determined by the discourse generation strategies (Dijk \& Kintsch, 1983, pp. 243-245). That is why in our analysis we use the term superstructure in the meaning of semantic structure typical of this or that discourse genre. It was proved in a number of experiments by cognitive psychologists and linguists that authors who regularly create discourse of a certain genre are guided by such superstructures which are present in their minds (Liddy, 1991). The contents are always different but there is a conventional schema of their structuring for reflecting in the discourse.

We should note the difference between the notion of superstructure and composition. The notion of composition is often used in discourse linguistics studies and means a form of discourse structuring into semantic blocks which are comparatively complete in the discourse space. As our analysis has shown, opposite to compositional blocks, superstructural categories can be represented in different parts of discourse space. They are not always discrete units but can be interspersed and recursive in the discourse space.

In determining superstructures of discourse genres as mental categories, we proceed from the assumption that they can be established on the basis of their language representations in discourse, because superstructural 
categories on the surface level are often signaled by certain discourse markers. Such markers can be separate words, lexical clichés, lexico-semantic groups of words, and lexical and syntactic structures. Superstructures can include a different number of categories but not all of them are expressed in the discourse of this or that genre. That is why we suggest differentiating between a prototypical superstructure and a detailed structure. The former includes the categories which are regularly represented in the discourse of this or that genre; hence the prototypical superstructure is the most frequent structure.

The second cognitive parameter that we use in the cross-cultural analysis of media discourse genres is key concepts or conceptual dominants which regularly find language expression in the discourse of this or that genre. The definition of the term concept as one of the main format of knowledge mental representation remains disputable in linguistics. In our research, we rely on the following definition given in the Dictionary of Cognitive Terms by Kubryakova, Dem'jankov, Pankrac, and Luzina (1996): The concept is "a unit of mental and psychic resources of our conscience and information structure which reflects a person's knowledge and experience" (p. 90).

We share the opinion of those linguists (Karasik, 2002), who distinguish three constituents in the structure of the concept: The first is the notion component, i.e., referring to the notion; the second is image-bearing and the third is the value component. The notion part is the definition structure which can be revealed on the basis of explanatory dictionaries; the image-bearing part is represented by metaphors and other tropes in discourse; the value part reflects the importance of the concept for the individual and the social group or the whole society and is often expressed by sentences.

\section{Results and Discussion}

Using the above mentioned theoretical premises, we analyzed the media discourse genre of a portrait feature story in American and Belarusian press. As a result, the prototypical structure was found to be "the portrait of the protagonist-background". Most of the semantic categories in the discourse are represented by a number of subcategories, e.g., "the portrait of the protagonist" may be represented in the media discourse by the subcategories of career, views, moral qualities, and plans. The category "background" is further subdivided into the evidence of colleagues, friends, and family members.

The semantic category "the portrait of the protagonist" can be verbalized right away in the headline, indicating the name of the character, described in the further discourse, her or his qualities (see Examples (1)-(2)), professional characteristics (see Examples (3)-(4)), views (see Examples (5)-(6)).

Example (1) Clinton magic at work on campaign trail (Miga, 2012, The Seattle Times).

Example (2) Вечна малады Андрэй Заспіцкі (Kanuta, 2013, Zvyazda).

Example (3) A big career, a small regret (Lohr, 2009, The New York Times).

Example (4) "Наш прафесар" (Myadzvedzeva, 2014, Zvyazda).

Example (5) When keeping quiet may be just the right thing to do (Harwood, 2009, The New York Times).

Example (6) "Вёску на горад не прамяняю!” (Radzuk, 2014, Zvyazda).

The beginning of the portrait feature story, usually the first paragraph, often gives the explanation why this very person has become the main character of the media discourse. The motives for creating such discourse are usually as follows: achievement in the professional life, a remarkable event, and circumstances of getting 
acquainted. In American press, the most frequent motive for creating such discourse is achievement in the professional life (see Example (7)), while in Belarusian press two motives are equally frequent: professional achievement and a remarkable event (see Example (8)).

Example (7) New "Bourne" star takes in stride his evolution into a leading man (Freydkin, 2012, The New York Times).

Example (8) Сёння патрыярху беларускага жывапісу, заслужанаму дзеячу мастацтваў Беларусі Пятру Алексеевічу Данеліі спаўняецца дзевяноста! (Krepak, 2010, Kultura).

The subcategories which constitute the two prototypical semantic categories of portrait feature stories have different figures of occurrence in the discourse. Thus, the highest degree of occurrence has the subcategory "career", which usually occupies most of the discourse space of the genre under study. It is signaled by concrete discourse markers being in the first place terminological words and phrases, reflecting the professional activities of the protagonist. In the discourse the category "career" is often subdivided into such subcategories as education, stages of the career, job duties, professional achievements, corporate structure, etc.

The portrait of the main character is also created through the semantic category "views", which makes the narration more subjective-oriented and helps the journalist avoid formal characterization. In the discourse the views of the protagonist are often expressed by syntactic structures with direct or indirect speech (see Example (9)).

Example (9) "If you do things, whether it's acting or music or painting, do it without fear...", he says. "Because nobody can arrest you and put you in jail if you paint badly..." (Puig, 2010, USA Today).

The cross-cultural analysis of the portrait feature stories from the two media cultures has revealed, on the whole, similarities in their superstructures. But there are some differences. While it is common for both the media cultures to devote portrait feature stories to famous persons in such spheres as cinema, literature, sports, business, and others, in Belarusian press the hero of this media genre is quite often an ordinary person who may present interest to the reader from the viewpoint of professional activities, decision-making, attitude to the people around, or even hobbies (see Example (10)).

Example (10) Два гады таму жыхары вёскі Веляцін аднадушна выбралі сваім упаўнаважаным Сяргея Аляксадравіча Крысенку—чалавека, які разумее патрэбы і праблемы землякоў... (Bosak, 2012, Zvyazda).

The peculiarity of portrait feature stories in American press is the presence of the semantic category "scandal" which can also serve as the motive for creating such discourse. For example, the beginning of one of the stories describes the activity of the successful businessman who was charged with conspiracy to commit securities fraud (see Example (11)).

Example (11) The 53-year-old veteran, a senior vice president...was arrested last week and accused of leaking sensitive data as part of an insider-trading ring... (Bulkeley, 2009, The Wall Street Journal).

The motive scandal explains the choice of the protagonist and also the discursive realization of the category "personal qualities". American media discourse alongside with positive traits of the character (brilliant, influential, prominent, successful, wise, etc.), includes negative or ironical characteristics of the protagonist: deceptive conduct, a discreet tycoon, a dreadful human-being, lavish life, etc. In Belarusian press these are only positive traits: адказны—“'responsible”, сціплы—“modest”, працавіты-“hard-working”, etc.

Now let us consider the second lingua-cognitive parameter of the discourse genre analysis undertaken in this 
paper-conceptual dominants (key concepts). As a result of the analysis, it is found out that the common concepts that are regularly verbalized in portrait feature stories of the two media cultures are those of "success" and "work". These concepts correlate with the semantic structure of this genre which includes the semantic category "career", disclosing the successful professional activities of the main character.

The notion part of the conceptual dominant "success" is reflected in the dictionary definitions and can be verbalized in American and Belarusian media discourse directly by the words поспех- "success", паспяховы-“successful”, паспяхова-“successfully". But more often this concept is represented in both the discourses indirectly through the description of the actions and results of successful activities (see Example (12)).

Example (12) His high-profile role also gives him the chance to enhance his legacy as Democratic elder statesman and global humanitarian (Miga, 2012, The Seattle Times).

The image-bearing part of this concept is very seldom expressed in American press, while in Belarusian discourse it is often verbalized in trite metaphors, similes, phrasal units, and proverbs. In the discourse space, it is represented in the semantic categories "career" and "evidence of colleagues" (see Example (13)).

Example (13) Як толькі не называюць Мальдзіса! Хадзячай энцыклапедыяй, чалавекам-аркестрам, куфарам ведаў, літаратуразнаўчай школай (Minkevich, 2012, Narodnaya Gazeta).

The value constituent of the concept "success" is represented in American and Belarusian media discourse by whole utterances. They are located in the discourse parts, referring to the semantic categories of career, evidence of colleagues and specialists (see Examples (14)-(15)).

Example (14) "I can't tell you how many people it takes to replace him", Cashman said. "He was the ticket manager, the marketing director, the general manager..." (Vecsey, 2010, The New York Times).

Example (15) Беларусь абавязана гэтаму чалавеку стварэннем службы дзіцячай неўралогіi, якой па паўнаце і наладжанасці няма роўных на ўсёй прасторы былога Саюза (Myadzvedzeva, 2014, Zvyazda).

The conceptual dominant "work" has similar language means of representation of all its constituents as of the concept "success" in portrait feature stories published in American and Belarusian press.

A specific characteristic of American portrait feature stories is the use of language means representing the concept "failure" which is determined by the presence of the category "scandal" in the semantic structure of the genre. This concept is realized in discourse mainly by indirect means: fraud, conspiracy, an alleged conspirator, to bolster, to cheat, to lie, to misrepresent, etc. The image-bearing part of the concept "failure" is often expressed by epithets: ill-conceived project, ill-fated deals, despicable treachery, lavish life, etc. The value constituent of this concept means the damage brought to society, companies, or individuals by the ill actions of the person described and can be expressed by concrete figures (see Example (16)).

Example (16) A man who swindled more than $\$ 17$ million from banks, friends... (Haughney, 2010, The New York Times).

It should be noted that in American portrait feature stories devoted to persons who cross the line into criminal activities the concept "success" is also reflected. We can suppose that it is done to give a full portrait of the protagonist and to determine the possible causes of breaking the law. In Belarusian media discourse the semantic category "scandal" and the correlating concept "failure" are represented in other media discourse genres: news stories, opinion articles, and commentaries. 


\section{Conclusion}

In conclusion, we can state that the lingua-cognitive analysis of portrait feature stories in American and Belarusian media discourse from the cross-cultural perspective has revealed their similar and specific properties. Similarities concern the prototypical superstructure of this genre, the set of conceptual dominants that are realized in the same semantic categories of the discourse space and language means of their representation.

On the other hand, we single out some differences which are manifested in the presence of the specific superstructural elements and conceptual dominants, also in the language means of representing some semantic subcategories and the image-bearing part of the concepts. We explain these differences by the lingua-cultural specificity of choosing by the journalists the thematic and semantic structure of the discourse as a whole.

The practical value of the research lies in the possibility of using the findings in teaching foreign languages, in particular, in the disciplines of discourse interpretation and stylistic analysis. The results can also be applied to developing algorithms of discourse summarization by computer.

\section{References}

Bosak, K. (2012, March 3). Хто ў вёсцы галоўны? (Who is head in the village?). Zvyazda.

Bulkeley, W. M. (2009, October 19). Moffat viewed as "Classic IBM Executive". The Wall Street Journal.

Dijk, T. A. van, \& Kintsch, W. (1983). Strategies of discourse comprehension. New York: Academic Press.

Freydkin, D. (2012, August 9). Jeremy Renner has that A-list look. USA Today.

Harwood, J. (2009, October 19). When keeping quiet may be just the right thing to do. The New York Times.

Haughney, Ch. (2010, September 21). A high flier in real estate is sentenced. The New York Times.

Kanuta, V. (2013, December 6). Вечна малады Андрэй Заспіцкі (For ever young Andrei Zaspitski). Zvyazda.

Karasik, V. I. (2002). Yazikovoy krug: lichnost', kontsepty, diskurs (Language circle: Personality, concepts, discourse). Volgograd: Peremena.

Karpilovitch, T. (2010). Kommunikativno-kognitivnoe modelirovanie diskursivnykh zhanrov (Communicative-cognitive modeling of discourse genres). Proceedings of the International Conference "Language-cognition-communication", Minsk.

Krepak, B. (2010, January 23). "Палеская ўсмешлівасць” інтуітыўнага матэматыка ("Palessya smile” of the intuitive mathematician). Kultura.

Kubryakova, E. S., Dem'jankov, V. Z., Pankrac, J. G., \& Luzina, L. G. (1996). Kratkij slovar' kognitivnyh terminov (Short dictionary of cognitive terms). Moskva: MGU.

Liddy, E. D. (1991). The discourse-level structure of empirical abstracts: An exploratory study. Information Processing and Management, 1, 55-81.

Lohr, S. (2009, October 19). A big career, a small regret. The New York Times.

Miga, A. (2012, October 14). Clinton magic at work on campaign trail. The Seattle Times.

Minkevich, L. (2012, August 23). Вядомаму беларускаму навукоўцу Адаму Мальдзісу-80 гадоў (Famous Belarusian scientist Adam Maldzis turns 80). Narodnaya Gazeta.

Minsky, M. (1975). A framework for representing knowledge. In P. H. Winston (Ed.), The psychology of computer vision. New York: McGraw-Hill.

Myadzvedzeva, V. (2014, December 6). Наш прафеcap (Our professor). Zvyazda.

Puig, C. (2010, September 21). Anthony Hopkins: Portrait of an artist. USA Today.

Radzuk, K. (2014, November 5). “Вёску на горад не прамяняю!” (I will not trade village for city!). Zvyazda.

Sinclair, J. M. (1992). Priorities in discourse analysis. In M. Coulthard (Ed.), Advances in spoken discourse analysis. London: Routledge, 79-88.

Thorndyke, P. W. (1977). Cognitive structures in comprehension and memory of narrative discourse. Cognitive Psychology, 9 , 77-110.

Vecsey, G. (2010, September 21). The boss remembered, fondly. The New York Times. 